Article

\title{
Sustainability and Financial Performance of Companies in the Energy Sector in Romania
}

\author{
Dragos Paun \\ Faculty of Business, Universitatea Babes-Bolyai, 400174 Cluj-Napoca, Romania; dragos.paun@tbs.ubbcluj.ro; \\ Tel.: +4-0744920449
}

Received: 29 August 2017; Accepted: 20 September 2017; Published: 25 September 2017

\begin{abstract}
In the article, we focus on the question of sustainability in the renewable energy sector of Romania. The aim of the current paper is to analyze the financial performance of the companies operating in the field. Our assumption is that the success of the implementation of the energy switch from classic to renewables relies on the businesses operating in this industry. In our article, we have selected the most prominent players in the energy industry, comparing the performance of those that are producing renewable energy to the ones that are producing energy using fossil fuels. Our analysis has shown that, starting with 2013, the companies have encountered financial difficulties, which has led to a halt in investments and the questioning of the sustainability of entering the market. After analyzing the data, we have seen that the investments have been rather opportunistic, based on the commitment of the government to keep the subsidies introduced by the policy, and have not been based on the realistic long-term financial performance of the companies in this area.
\end{abstract}

Keywords: financial performance; renewable energy policy; net income; sustainability

\section{Introduction}

Energy and energy independence have been some of the most widely debated issues over the past few years. Many of the European countries rely on the import of gas and energy and as past experience has shown, this dependence can be harmful in the case of a conflict or increase in price. Furthermore, most nuclear energy-producing facilities are vulnerable to harm, and could prove to be harmful (see the Fukushima Daiichi nuclear disaster for example). At the European level, the drivers of the switch to renewable energy was Agenda 2020, which includes energy among its priorities. Additionally, we have seen that, in numerous countries, the energy sector has become of great interest. Apart from the already mentioned energy independence there is also a need to find solutions for sustainable development and to tackle the impact of fossil fuels on the environment [1] (see, for instance, Germany's Energiewende).

Kitzing et al. [2] present in their study the mechanisms that the various European Union Member States have put into practice to attain the different levels that where imposed by the European Union through Agenda 2020 and the Directive 2009/28/EC [3]. As there is no common structure for the implementation of Agenda 2020, each Member State has introduced its own policy, by creating a very diverse systems with support schemes that include feed-in tariffs, feed-in premiums, quota obligations for distributors, investment grants, financing support, green certificates, etc.

The current paper analyzes the sustainability of the renewable energy sector in Romania providing financial information on the companies and analyzing their performance. The sustainable development of the renewable energy sector relies on the existence of suppliers and a demand for their output. The novelty of this studying lies in its linking the switch to renewable energy to the financial performance of the companies operating. In our study, we have compared companies producing renewable energy to the ones producing energy from traditional sources.

Our aim has been to examine whether there is a difference in the financial performance of the companies. A second objective has been to verify whether the companies might be regarded as 
sustainable, to the extent of completing the switch to renewable energy. Another objective has been to analyze how government support can help this sector, as the investment in production capacities is asset-intensive and would require heavy funding on the part of investors. Our assumption is that the development of the renewable energy production sector is strongly linked to the stability of the companies operating in the sector.

The financial performance of the companies is based on the years 2012-2015. Wind farms have been set up in Romania since 2009, but the first solar farms have emerged only in 2012. The last year that we have analyzed is 2015 , as there is currently no public information related to 2016. Although various methods could be used to analyze the financial performance we have focused our article on the profitability and the capital structure of the companies. Similar work has been conducted by Capece [4] focusing on the gas retail market.

\section{Literature Review}

It is not necessary to dispute the need for a switch towards green energy. Several studies have focused their attention on the harmful effects of the classic energy sources [5]. Most of the studies analyzed do not look at the companies producing, but they look at the end goal of our study, i.e., the possibility to achieve a complete switch to renewable energy sources (RES). Lehmann [6] has investigated the feasibility of Japan supporting $100 \%$ of its energy through RES, Krajačić et al. [7] have elaborated a study on the island of Mljet in Croatia, Lund and Mathiesen [8] have investigated the possibility of Denmark switching to $100 \%$ RES, and Connolly et al. [9] have presented the technical and economic impact of a 100\% renewable energy scenario for the EU. Their study exhibits a nine-step transition from primary fossil fuels to renewable energy. What is problematic about this study is that even though it takes into account the cost of the investment and the energy cost but it does not look at the financial stability of the companies involved in the process. Mundaca and Markandya [10] provide an overview of the regional progresses of the switch to green energy, concluding that despite the multitude of policies, the impact remains insufficient.

The switch towards a more environmentally friendly vision can also be observed at the local level with cities like Aspen (Colorado), Burlington (Vermont), and Greensburg (Kansas) already using 100\% renewable energy, and others like Copenhagen, Sønderborg, Aalborg, Flensburg, and Seattle switching to $100 \%$ RES or with a target of $\mathrm{CO}_{2}$ neutrality in the future.

At the micro level, the attention is particularly focused on companies operating in this sector, whilst at the macro level the main concerns are the trends and prospects of energy supply and demand. However, overall, these models attempt to better capture the interactions taking place within the sector, as well as those between this sector and the other components of the economy, outlining the position of the energy sector.

Bobinaite [11] focuses her study on the sustainability of the wind power sector in the Baltic States. The investments in the renewable energy sector would not have been possible without the state support programs. The study also shows that the financial stability of the companies is moderate but with time there is some improvement in time. Ming et al. [12] have analyzed the renewable energy investment and financing in China, focusing their study on the wind farms and the solar energy. Gupta [13] has studied the effects of economic and societal factors on the financial performance of alternative energy. His results indicate that that an increase in local market return, oil prices, or technology stock prices positively influences the stock returns of alternative energy firms. He also finds that in countries where the technology and innovation are developed, alternative energy firms have higher benefits.

Other studies have focused on the differences between the price of the various types of energy on the stock market [14,15]. Other analysis types, such as Bohl's study [16], could not be reproduced for the Romanian market as there are few companies that operate in the renewable energy sector and that are listed on the stock exchange.

The Europe Agenda 2020 was set to create a real change for the people living in the EU [17]. In order to meet the targets established by the Europe Agenda 2020 with regards to energy, the Romanian 
Government has introduced the Electrical Energy Law [18], with subsequent amendments [19] and [20]. The introduction of this legislation has generated an increase in investments in Romania. A study that focuses on the impact of renewable energy on the economy has been published by Paun and Paun [21]. The success of the law can be quantified if we look at the share of electricity produced from renewable sources in the gross final consumption of electricity in the country in 2013, which was $41 \%$, above the target of $38 \%$ assumed by Romania for 2020, and over the intermediate target of $35 \%$ indicated for 2015, according to the Ministry for Energy. Additionally, Romania has negotiated with the European Commission that $24 \%$ its of total energy consumption will be from renewable sources by 2020 . This target includes both electricity and heat energy and fuels. The National Energy Regulatory Authority (ANRE) announced that this target had already been reached on 1 January 2014. For the electricity segment, the target set for 2020 is 38\%, while the intermediate target for 2015 was 35\%. However, according to the information provided by authorities, Romania has already exceeded both thresholds. This is mainly due to two factors. Firstly, Romania has a well-developed hydro energy network which constantly provides over $20 \%$ of the energy in the grid. Secondly, renewable energy production was promoted through a support program which obliged companies selling energy to have a certain amount of energy purchased from RES. The source of energy could only be proven with the help of green energy certificates, which were sold by the renewable energy producers. Renewable energy producers receive a certain number of green certificates for each MW delivered into the grid [22]. Thus, besides earning money from the sale of energy, these producers would also earn money from the sale of green certificates. The value of one green certificate has varied in time between 27 and 55 euros. This support program has created an incentive that has attracted around 8 billion euros in investments from 2006 to 2010. With energy expenses for the population increasing (due to the incorporation of the new cost related to green certificates), the government has decided in 2012 to postpone the issuance of green certificates and has lowered the quota of green energy sold. This has stopped one of the sources of revenue for companies producing renewable energy and has led to financial difficulties for such companies, putting a strain on the entire system. One of the objectives of this paper was to see whether the decision has led to major issues.

Furthermore, countries such as Spain, Italy, Greece, Bulgaria, Poland, Germany, and the Czech Republic have assumed targets related to the share of renewable energy in total energy consumption by 2020 that are less than the target of Romania (24\%), except Estonia, which has a target of $25 \%$.

The data published by the National Institute of Statistics on energy resources, Tables 1 and 2, shows that in 2015 primary energy resources increased by $2.0 \%$ and electricity production grew by $7.8 \%$, compared to 2014. Primary energy resources in 2015 totaled 32.8736 million tons of oil equivalent, an increase of 652,400 tons of oil equivalent compared to 2014.

Domestic production totaled 220,426 million tons of oil equivalent, an increase of 163,900 tons of oil equivalent compared to the previous year, while imports were at 1.0831 thousand tons of oil equivalent. Moreover, in 2015 electricity resources were 6.9373 million $\mathrm{kWh}$, recording an increase of 5.0135 billion $\mathrm{kWh}(+7.8 \%)$ compared to 2014 .

The output of power plants was 28.2387 billion $\mathrm{kWh}$ increasing by 1646.0 million $\mathrm{kWh}(+6.2 \%)$. The output of hydropower plants was 16.6865 billion $\mathrm{kWh}$, decreasing by 2311.0 million $\mathrm{kWh}(-12.2 \%)$ and the output of nuclear power stations was 11.6398 billion $\mathrm{kWh}$, decreasing by 35.8 million $\mathrm{kWh}(-0.3 \%)$.

During the year (2015), the output of wind power stations was 7.0448 billion $\mathrm{kWh}$, reporting an increase of 2.3212 billion $\mathrm{kWh}$ compared to 2014, while the photovoltaic solar energy produced in this period was 1.9874 billion $\mathrm{kWh}$, up by 692.1 million $\mathrm{kWh}$ compared to 2014 . 
Table 1. The main primary energy resources in thousand tons of oil equivalent.

\begin{tabular}{|c|c|c|c|c|c|c|c|c|c|}
\hline \multirow[t]{2}{*}{ Name/Year } & \multicolumn{3}{|c|}{2015} & \multicolumn{3}{|c|}{$\begin{array}{l}2015 \text { Compared to } 2014 \text { Differences } \\
\qquad( \pm)\end{array}$} & \multicolumn{3}{|c|}{$\%$} \\
\hline & Total & Production & Import & Total & Production & Import & Total & Production & Import \\
\hline $\begin{array}{l}\text { Resources-total } \\
\text { From which: }\end{array}$ & $32,873.6$ & $22,042.6$ & $10,831.0$ & +652.4 & +163.9 & +488.5 & 102.0 & 100.7 & 104.7 \\
\hline Net coal & 5235.2 & 4678.8 & 556.4 & +332.2 & +277.2 & +55.0 & 106.8 & 106.3 & 111.0 \\
\hline Oil & $10,333.6$ & 3738.1 & 6595.5 & -182.1 & -50.2 & -131.9 & 98.3 & 98.7 & 98.0 \\
\hline Usable natural gas & 8722.1 & 8560.4 & 161.7 & -399.1 & $-114,7$ & -284.4 & 95.6 & 98.7 & 36.2 \\
\hline Hydroelectric power & 5390.0 & 5065.3 & 324.7 & +283.9 & +51.6 & +232.3 & 105.6 & 101,0 & 351.4 \\
\hline Nuclear energy_electricity and electricity imports & & & & & & & & & \\
\hline Imported petroleum products & 2690.2 & _ & 2690.2 & +579.8 & _ & +579.8 & 127.5 & _- & 127.5 \\
\hline
\end{tabular}

Source: National Institute of Statistics.

Table 2. Electrical power balance.

\begin{tabular}{lccc}
\hline Name/Year & $\mathbf{2 0 1 5}$ & $\mathbf{2 0 1 5}$ Compared to 2014 \\
\hline & Millions kWh & Differences $( \pm$ ) & \% \\
\hline & & Millions kWh & \\
\hline Resources-total & $69,373.0$ & +5013.5 & 107.8 \\
- Production & $65,597.2$ & +2312.5 & 103.7 \\
- in classical power plants & $28,238.7$ & +1646.0 & 106.2 \\
- in hydro power plants & $16,686.5$ & -2311.0 & 87.8 \\
- in nuclear power plants & $11,639.8$ & -35.8 & 99.7 \\
- in wind power plants & 7044.8 & +2321.2 & 149.1 \\
- in photovoltaic solar plant & 1987.4 & +692.1 & 153.4 \\
- Import & 3775.8 & +2701.0 & 351.3 \\
Destinations-total & $69,373.0$ & +5013.5 & 107.8 \\
- Final consumption & $52,565.0$ & +2955.1 & 106.0 \\
- in economy & $39,937.9$ & +2381.1 & 106.3 \\
- public lighting & 601.3 & +140.8 & 130.6 \\
- population & $12,025.8$ & +433.2 & 103.7 \\
- Domestic consumption in networks and stations & 6304.3 & -245.4 & 96.3 \\
- Export & $10,503.7$ & +2303.8 & 128.1 \\
\hline
\end{tabular}

Source: National Institute of Statistics. 
The final consumption of electricity in this period was 52,565.0 million $\mathrm{kWh}$, with $6.0 \%$ higher than in 2014; public lighting increased by $30.6 \%$, while household consumption increased by $3.7 \%$. Exports of electricity stood at 10.5037 billion $\mathrm{kWh}$, marking an increase of 2.3038 billion $\mathrm{kWh}$. Domestic consumption in networks and stations was 6.3043 billion $\mathrm{kWh}$, decreasing by 245.4 million $\mathrm{kWh}$.

The tables below highlight the overall situation of energy resources for 2015, and the changes that occurred in 2015 compared to 2014. In the first table we can see the production/import of main primary energy resources, while the second table displays the electrical power balance.

\section{Materials and Methods}

The aim of this paper is to analyze the financial performance of the companies operating in the Romanian energy sector. The source of the financial data was the public information obtained from the National Company Register and Ministry of Finance. The National Company Registry has around 500 companies listed as energy producers. In our analysis, we have only taken the ones that are able to produce energy at a regular rate and that have the possibility of varying the delivery of energy into the grid according to the needs. We considered that it would have rendered the analysis redundant if we had considered the companies that produce energy under a certain level and are not able to respond to the needs of the National Agency for Energy with regard to changing their production capacity. Thus, from the actual 500 companies, only $20 \%$ are able to produce energy on a constant basis and to react to the market needs. We have analyzed 91 major energy producers using the financial data from the years 2012, 2013, 2014, and 2015, the latest data provided by the Ministry of Public Finance for the selected companies. The companies were clustered according to the type of energy produced. Nineteen of the companies are classic energy producers, 39 companies produce energy from wind farms and 33 of the companies use solar panels for their production. The data that we have used and which is related to the consumption of the energy and investments was obtained from the National Institute of Statistics and from the National Agency for Regulation in the Energy Industry.

In order to see whether the policy has the potential to make a long-term change in the Romanian market, and perhaps prompt, in the foreseeable future cities to switch entirely to renewable energy, we have used elements from the financial statement analysis method in order to paint a precise picture of the companies operating in the energy industry. Given the data that was publicly available we have used ratio analysis to see how the companies are performing [23], and we have used the horizontal analysis to analyze the trends in the industry [24]. We have resorted to the most commonly used profitability ratios, return on equity and return on assets to see whether the investments in the companies belonging to the energy sector were successful. We have not used return on investment as this would require a much larger dataset. Given the short time of the existence of the investments, most of the ROI for the companies producing green energy would have been negative and, thus, not conclusive for our study. Another frequently used ratio for the profitability analysis is return on sales, but in this case, too, we have encountered problems with the fact that the companies do not merely have only one source of revenue (the sale of energy) given the sale of green certificates. We have also used a ratio to examine the capacity of the companies to pay off their debt, total assets to total debt ratio. Another ratio that could provide information on the capacity of the companies to meet their short-term obligations is the current ratio. This ratio has not been used because the majority of the companies have low levels of current assets and, thus, most of the time also have low short-term liabilities. As mentioned already investments in energy production are asset intensive requiring the purchase of long-term assets. The average percentage of non-current assets in the industry in the period of time analyzed is $86.5 \%$.

We have chosen the return on equity ratio because it compares the equity invested to the net income of the company and it provides a measure to analyze the success of the investments. A high ROE may indicate the firm is able to find investment opportunities that are very profitable [25].

The return on assets is calculated as the net income divided by the book value of assets. However, Berk and DeMarzo make the point that by merely taking into account the net income, one would 
not consider the fact that some assets generate income that is not taken into consideration due to the financing of the assets, i.e., interest expenses that are paid because most of the assets in the industry are financed through debt. Even though the companies that we have analyzed in the paper have a high amount of debt registered, we have not used the formula that excludes interest expenses.

We have also analyzed the capacity of the companies to pay off their debt by using their assets. Thus, we have calculated the total assets to total debt ratio to see whether the companies own assets that would allow them to cover their debt. A ratio above $100 \%$ would mean that there is no problem in covering the debt with the value of the assets, while a percentage below 100 would mean that the company has serious issues, which could lead to insolvency.

\section{Results and Discussion}

The global economic crisis had a different impact on companies' performance, depending on the type of source used to produce electricity. For instance, from 2009, the financial performance of companies which use classical sources in order to generate electricity exhibited an upward trend, until 2010, when there was a sharp decline and trend reversed.

In contrast, wind farms recorded a fall in net profit over the year 2009, but as of 2010 the situation gradually improved and the upward trend was maintained until the beginning of 2013. In the case of firms which use photovoltaic sources, the trend remained constant between 2009 and 2013 (net profit was around zero). As Table 3 shows beginning with 2013 the financial performance of all companies decreased slightly, following a downward trend throughout the year.

The results in Table 4 show that from the 91 companies studied, 42 of them had a higher value of the debt than the one of the assets in 2015. We see that there was an improvement over the year which shows that even though the situation was not optimal, the companies managed to pay off their debt to increase their ratio above $100 \%$. The companies operating wind farms had the best results, with $33 \%$ of such companies having their total assets to total debt ratio higher than $150 \%$.

Table 3. Percentage in change in the companies' net profit (sum).

\begin{tabular}{cccc}
\hline Source Type/Year & $\mathbf{2 0 1 2 - 2 0 1 3}$ & $\mathbf{2 0 1 3 - 2 0 1 4}$ & $\mathbf{2 0 1 4 - 2 0 1 5}$ \\
\hline Wind power & $9494.19 \%$ & $-529.84 \%$ & $-20.10 \%$ \\
Photovoltaic & $989.52 \%$ & $1822.55 \%$ & $-41.65 \%$ \\
Classical & $-685.08 \%$ & $-99.03 \%$ & $34,736.7 \%$ \\
\hline
\end{tabular}

Source: Own calculations.

Table 4. Total assets to total debt ratio for companies.

\begin{tabular}{clcccc}
\hline & & $\mathbf{2 0 1 2}$ & $\mathbf{2 0 1 3}$ & $\mathbf{2 0 1 4}$ & $\mathbf{2 0 1 5}$ \\
\cline { 3 - 6 } & & \multicolumn{3}{c}{ Number of Companies } \\
\hline \multirow{3}{*}{ Energy from } & Lower than $50 \%$ & 0 & 1 & 0 & 2 \\
Wind Farms & Between $50 \%$ and $100 \%$ & 9 & 8 & 14 & 13 \\
& Higher than $150 \%$ & 21 & 16 & 12 & 11 \\
& Lower than $50 \%$ & 9 & 14 & 13 & 13 \\
\hline \multirow{2}{*}{ Energy from } & Between $50 \%$ and $100 \%$ & $140 \%$ & 14 & 14 & 12 \\
solar panels & Between $100 \%$ and $150 \%$ & 14 & 14 & 15 & 17 \\
& Higher than $150 \%$ & 3 & 4 & 3 & 3 \\
\hline \multirow{2}{*}{ Energy from } & Lower than $50 \%$ & 2 & 2 & 2 & 0 \\
classic producers & Between $50 \%$ and $100 \%$ & 4 & 5 & 3 & 12 \\
& Between $100 \%$ and $150 \%$ & 6 & 6 & 7 & 17 \\
& Higher than $150 \%$ & 8 & 7 & 8 & 3 \\
\hline
\end{tabular}

Source: own calculations.

The results of the ROE analysis (Table 5) are in accordance with the study by Capece [4]. Even though his analysis was conducted on companies operating in the gas retail market during the period 
2004-2006 their ROE is situated between $2 \%$ and $4 \%$. The study by Bobinaite [11] has similar results with companies having an ROE ranging from $4 \%$ to $16 \%$ in the Baltic States. Her study also shows a drop in the profitability of companies operating in the RES starting with 2014, similar to our study. These results are not encouraging if we look at the fact that only $31.86 \%$ of the companies have an ROE which is higher than $10 \%$. Investors most of the time expect an ROE which is higher than $10 \%$. Aswath Damodaran [26], from the Stern School of Business at New York University compared the calculated average ROE of different industries using data available in January 2016. Thus, in his analysis he has a market ROE of $10.77 \%$ with some industries well over this: $45.64 \%$ retail—building supply; $44.13 \%$ —air transport; $32.23 \%$-computer services; $21.81 \%$-auto parts; and $21.92 \%$-entertainment. Investors always looking for good business and high returns, so this would discourage investments in Romania's energy sector. However, if we would compare the results of the ROE with the specific market we see that the average ROE for coal and related energy is $-31 / 49 \%$, and for green and renewable energy, $-4.06 \%$. If we compare the industries, we see that there are companies which could be interesting for investors, even though the average ROE for those companies is $-624,041.879 \%$ and the median $-34.642 \%$. This is due to the fact that over 18 companies had an ROE which exhibited a minus of at least five figures. These figures are explained through the fact that, in Romania, the minimum capital requirement for companies is 200 lei (45 euros) while the loss reported by companies is very high.

When we look at the results of the analysis of the ROA for the companies studied (Table 6) we see that such results are once again in line with similar studies on company performance. In the Baltic States, the ROA ranges in the period $2011-2013$, from $5 \%$ to $-19 \%$. This is not a surprising issue due to the fact that most of the companies have a high value of assets.

Table 5. Return on equity of companies.

\begin{tabular}{clcccc}
\hline & & $\mathbf{2 0 1 2}$ & $\mathbf{2 0 1 3}$ & $\mathbf{2 0 1 4}$ & $\mathbf{2 0 1 5}$ \\
\cline { 3 - 6 } & & \multicolumn{3}{c}{ Number of Companies } \\
\hline \multirow{3}{*}{ Energy from } & Negative & 21 & 16 & 33 & 16 \\
Wind Farms & Lower than $10 \%$ & 4 & 6 & 3 & 6 \\
& Between $10 \%$ and $20 \%$ & 0 & 3 & 0 & 3 \\
& Higher than $20 \%$ & 14 & 14 & 3 & 14 \\
\hline \multirow{3}{*}{ Energy from } & Negative & 20 & 21 & 24 & 22 \\
solar panels & Lower than $10 \%$ & 1 & 0 & 2 & 3 \\
& Between $10 \%$ and $20 \%$ & 1 & 0 & 1 & 1 \\
& Higher than $20 \%$ & 10 & 11 & 5 & 6 \\
\hline \multirow{3}{*}{ Energy from } & Negative & 9 & 9 & 9 & 12 \\
classic producers & Lower than $10 \%$ & 3 & 2 & 2 & 3 \\
& Between $10 \%$ and $20 \%$ & 3 & 2 & 1 & 1 \\
& Higher than $20 \%$ & 5 & 7 & 8 & 4 \\
\hline
\end{tabular}

Source: own calculations.

Table 6. Return on assets for companies.

\begin{tabular}{clcccc}
\hline & & $\mathbf{2 0 1 2}$ & $\mathbf{2 0 1 3}$ & $\mathbf{2 0 1 4}$ & $\mathbf{2 0 1 5}$ \\
\cline { 3 - 6 } & Negative & 21 & 16 & 33 & 16 \\
& Lower than 3\% & 13 & 10 & 5 & 10 \\
Energy from & Between 3\% and 10\% & 5 & 13 & 0 & 13 \\
Wind Farms & Higher than 10\% & 0 & 0 & 1 & 0 \\
\hline \multirow{3}{*}{ Energy from } & Negative & 20 & 21 & 24 & 22 \\
solar panels & Lower than 3\% & 10 & 4 & 7 & 9 \\
& Between 3\% and 10\% & 2 & 5 & 1 & 1 \\
& Higher than 10\% & 0 & 2 & 0 & 0 \\
\hline \multirow{3}{*}{ Energy from } & Negative & 9 & 9 & 9 & 12 \\
classic producers & Lower than 3\% & 6 & 4 & 5 & 3 \\
& Between 3\% and 10\% & 3 & 6 & 4 & 4 \\
& Higher than 10\% & 2 & 1 & 2 & 1 \\
\hline
\end{tabular}

Source: own calculations. 
This is linked to the fact that the entire industry, not only renewables, is asset-intensive, see Table 7 for the net value of total assets. If we look at the costs of the companies dealing with renewables, we notice that a substantial part is related to the investment, i.e., amortization and depreciation of the assets. The cost with the employees, selling general and administrative costs are minimal due to the fact that most of the companies have reported $0-5$ employees (62 out of 71 ). This is also easily explained through the fact the companies are mostly controlled by software and there is no need to worry about the sale of energy as this automatically enters into the grid and is purchased by the distributors in accordance with the provisions of Romanian law.

Table 7. Total assets in the energy industry.

\begin{tabular}{cc}
\hline Year & Total Assets \\
\hline 2015 & $60,807,253,466$ \\
2014 & $63,783,113,449$ \\
2013 & $68,975,607,524$ \\
2012 & $64,245,952,881$ \\
\hline \multicolumn{2}{c}{ Source: own calculations. }
\end{tabular}

Based also on the results from the ROE and ROA and our profitability analysis we notice that investments stopped in 2013, when we had the last boom related to the operating of new wind farm production facilities. After 2013, with the change of government and the prolonging of the green certificates, the companies have avoided major investments, especially as the return of such companies has failed to be visible, which is in accordance with the results from Table 3.

When looking at the average and median values for the net income, turnover, and assets (Tables 8 and 9) we notice that while producers of renewable energy (wind farms) have a positive value for 2012 and 2013, those from classic sources have negative values. Solar producers also have a negative value, because they had just entered the market. As a group, the solar producers did not exhibit a positive value in the entire period which was analyzed. Starting with 2014, because of the government's decision to postpone green certificates, the producers of renewable energy have shown negative values, while profits seem to have switched to the classic producers until 2015, when all three categories yielded negative values for the net income.

Table 8. Average values for total assets, debt, equity, revenue, and net income.

\begin{tabular}{ccccccc}
\hline \multirow{2}{*}{ Year } & & Total Assets & Debt & Equity & Revenue & Net Income \\
\hline \multirow{2}{*}{2012} & Wind Average & $365,986,189$ & $236,623,225$ & $115,119,956$ & $53,362,112$ & 115,772 \\
& Solar Average & $19,575,135$ & $18,812,306$ & 802,176 & $3,264,431$ & $-148,575$ \\
& Classic Average & $2,465,443,636$ & $705,609,544$ & $1,693,903,731$ & $656,305,361$ & $-8,421,895$ \\
\hline \multirow{2}{*}{2013} & Wind Average & $415,207,234$ & $268,888,050$ & $131,934,828$ & $74,753,366$ & $11,107,350$ \\
& Solar Average & $101,317,323$ & $96,695,710$ & $3,427,642$ & $43,638,452$ & $-330,044$ \\
& Classic Average & $2,470,247,958$ & $619,552,083$ & $1,763,185,524$ & $798,594,695$ & $48,923,394$ \\
\hline \multirow{2}{*}{2014} & Wind Average & $357,917,184$ & $254,093,658$ & $79,309,718$ & $41,763,080$ & $-47,744,353$ \\
& Solar Average & $96,901,982$ & $91,764,256$ & 826,155 & $18,488,781$ & $-6,345,259$ \\
& Classic Average & $2,326,483,693$ & $572,297,047$ & $1,660,936,622$ & $710,216,784$ & 260,005 \\
\hline \multirow{2}{*}{2015} & Wind Average & $310,616,010$ & $234,789,828$ & $41,448,682$ & $46,814,161$ & $-38,149,188$ \\
& Solar Average & $95,312,274$ & $87,963,644$ & $-1,083,341$ & $19,697,207$ & $-3,702,185$ \\
& Classic Average & $2,272,630,588$ & $541,922,793$ & $1,541,497,327$ & $690,510,895$ & $-87,375,490$ \\
\hline
\end{tabular}


Table 9. Median values for total assets, debt, equity, revenue, and net income.

\begin{tabular}{ccccccc}
\hline \multirow{2}{*}{ Year } & & Total Assets & Debt & Equity & Revenue & Net Income \\
\hline \multirow{2}{*}{2012} & Wind Median & $365,986,189$ & $236,623,225$ & $115,119,956$ & $53,362,112$ & 115,772 \\
& Solar Median & $19,575,135$ & $18,812,306$ & 802,176 & $3,264,431$ & $-148,575$ \\
& Classic Median & $2,465,443,636$ & $705,609,544$ & $1,693,903,731$ & $656,305,361$ & $-8,421,895$ \\
\hline \multirow{2}{*}{2013} & Wind Median & $415,207,234$ & $268,888,050$ & $131,934,828$ & $74,753,366$ & $11,107,350$ \\
& Solar Median & $101,317,323$ & $96,695,710$ & $3,427,642$ & $43,638,452$ & $-330,044$ \\
& Classic Median & $2,470,247,958$ & $619,552,083$ & $1,763,185,524$ & $798,594,695$ & $48,923,394$ \\
\hline \multirow{2}{*}{2014} & Wind Median & $357,917,184$ & $254,093,658$ & $79,309,718$ & $41,763,080$ & $-47,744,353$ \\
& Solar Median & $96,901,982$ & $91,764,256$ & 826,155 & $18,488,781$ & $-6,345,259$ \\
& Classic Median & $2,326,483,693$ & $572,297,047$ & $1,660,936,622$ & $710,216,784$ & 260,005 \\
\hline \multirow{2}{*}{2015} & Wind Median & $310,616,010$ & $234,789,828$ & $41,448,682$ & $46,814,161$ & $-38,149,188$ \\
& Solar Median & $95,312,274$ & $87,963,644$ & $-1,083,341$ & $19,697,207$ & $-3,702,185$ \\
& Classic Median & $2,272,630,588$ & $541,922,793$ & $1,541,497,327$ & $690,510,895$ & $-87,375,490$ \\
\hline
\end{tabular}

Source: own calculations.

The ratio analysis has shown that the financial performance of the companies is questionable with most of the companies being close to financial distress. This result is in line with the studies conducted in the Baltic States [11], which concluded that there is a risk of bankruptcy in the case of companies operating in the RES. One of our aims has been to analyze whether there are differences between the companies operating in the energy production sector. The results of our work show that the entire sector suffers; in recent years we have seen that while classic energy producers perform better, producers from RES struggle more and more to keep their activity under control. The results of our study are also in line with Bohl [16] and his analysis on the companies producing alternative energy from the German stock market. His study concludes that the stocks "have turned into loser stocks after being perceived as fad stocks during the mid-2000s. In fact, we find that the outperformance for the years until 2008 was driven by explosive price behavior". In order to have a sustainable switch to RES one must also ensure that the companies producing the energy remain on the market. In our analysis we notice that, from the four years studied, the only companies that have a positive net income average are the classic energy providers. The involvement of the state in the production of RES could also provide the sustainable development of the industry but this would cause disturbances in the market, whilst in countries where the public expenses and the budgets are limited, this option is also limited. This is also the reason why the heavy subsidies for wind energy were postponed in 2012 and has created distress for companies.

\section{Conclusions}

We have started our analysis with a clear objective, i.e., to see whether there are any differences among the companies producing energy. Our analysis has concluded, similar to other studies, that most of the companies involved in the production of energy have had poor financial performance and that there were no major differences. Companies that are producing energy from fossil fuel have exhibited better performances, leaving only producers of green energy to face difficulties in the years to come without the active involvement of the government. To increase the financial performance companies must continue to innovate and improve business processes $[27,28]$. This can only be done with the help of the regulatory agencies, which would have to push more measures to raise public awareness about the need for a switch to RES. Most companies have already attempted to cut costs by using fewer labor force resources and introducing technology. A switch in people's mindset could also prove to be stimulating to industry. The conclusion of our analysis is that the sustainability of the companies operating in the renewable energy industry is questionable. The financial performance of companies operating in this industry was strongly linked to the subsidies received from the state, but the subsidy 
program was changed after a few years. In the early years of the investments, 2006-2010, the impact of the latter was still heavy - as mentioned in the article, investments in energy are asset-intensive and the depreciation costs affect the financial results of the companies during these initial years. This result is in accordance with the international trend because companies investing in this industry have high initial investments which cannot be recovered in the first years. As the Romanian market is only in its early stages, we notice that the companies have considerable debt. Thus, without heavy investments from the owner or subsidies from the state we do not see the market as being sustainable in the long-term. Another reason why the energy sector has such poor financial results is that the Romanian government has still not finalized the liberalization of the energy price. The sustainability of the energy industry is to be proven in the coming years, but at this point we cannot say that the financial results are much worse than the ones from the fossil fuel producers. Given the amount of publicly available information and the fact that the industry is still in its early stages of development, the research is limited and will be developed in future publications. The analysis could be developed by looking at the way that companies have financed themselves during this time and the efficiency of the financing instrument but, in our case, this would not have been in line with the objective of the paper.

Acknowledgments: This article has been written with the financial support of the European Commission through the Jean Monnet Project. The Jean Module Managing the EU-Taxation, Economics, and Governance 553356-EPP-2014-1-RO-EPPJMO-MODULE.

Conflicts of Interest: The author declares no conflict of interest.

\section{References}

1. Gavriletea, M.D.; Gavriletea, M.I. The effect of the energy to ecosystem and risk management solution for covering the potential loss. Ann. Fac. Econ. 2009, 3, 212-217.

2. Kitzing, L.; Mitchell, C.; Morthorst, P.E. Renewable energy policies in Europe: Converging or diverging? Energy Policy 2012, 51, 192-201. [CrossRef]

3. Commission, E. Directive 2009/28/EC of the European Parliament and of the Council of 23 April 2009 on the Promotion of the Use of Energy from Renewable Sources and Amending and Subsequently Repealing Directives 2001/77/EC and 2003/30/EC. Off. J. Eur. Union 2009, 140, 16-62.

4. Capece, G.; Cricelli, L.; Di Pillo, F.; Levialdi, N. A cluster analysis study based on profitability and financial indicators in the Italian gas retail market. Energy Policy 2010, 38, 3394-3402. [CrossRef]

5. Sueyoshi, T.; Goto, M. Environmental assessment on coal-fired power plants in U.S. north-east region by DEA non-radial measurement. Energy Econ. 2015, 50, 125-139.

6. Lehmann, H. Energy Rich Japan; G.I.a.G. Japan, Ed.; Institute for Sustainable Solutions and Innovations (ISUSI): Tokyo, Japan, 2003.

7. Krajačić, G.; Duić, N.; Carvalho, M.D.G. H2RES, Energy planning tool for island energy systems-The case of the Island of Mljet is. Int. J. Hydrogen Energy 2009, 34, 7015-7026. [CrossRef]

8. Lund, H.; Mathiesen, B.V. Energy system analysis of 100\% renewable energy systems-The case of Denmark in years 2030 and 2050. Energy 2009, 34, 524-531. [CrossRef]

9. Connolly, D.; Lund, H.; Mathiesen, B.V. Smart Energy Europe: The technical and economic impact of one potential 100\% renewable energy scenario for the European Union. Renew. Sustain. Energy Rev. 2016, 60, 1634-1653. [CrossRef]

10. Mundaca, L.; Markandya, A. Assessing regional progress towards a 'Green Energy Economy'. Appl. Energy 2016, 179, 1372-1394. [CrossRef]

11. Bobinaite, V. Financial sustainability of wind electricity sectors in the Baltic States. Renew. Sustain. Energy Rev. 2015, 47, 794-815. [CrossRef]

12. Ming, Z.; Ximei, L.; Yulong, L.; Lilin, P. Review of renewable energy investment and financing in China: Status, mode, issues and countermeasures. Renew. Sustain. Energy Rev. 2014, 31, 23-37. [CrossRef]

13. Gupta, K. Do economic and societal factors influence the financial performance of alternative energy firms? Energy Econ. 2017, 65, 172-182. [CrossRef] 
14. Kumar, S.; Managi, S.; Matsuda, A. Stock prices of clean energy firms, oil and carbon markets: A vector autoregressive analysis. Energy Econ. 2012, 34, 215-226. [CrossRef]

15. Managi, S.; Okimoto, T. Does the price of oil interact with clean energy prices in the stock market? Jpn. World Econ. 2013, 27, 1-9. [CrossRef]

16. Bohl, M.T.; Kaufmann, P.; Stephan, P.M. From hero to zero: Evidence of performance reversal and speculative bubbles in German renewable energy stocks. Energy Econ. 2013, 37, 40-51. [CrossRef]

17. Adrian-Gabriel, C. Europe 2020-An Agenda for Citizens and States. In Democracy and Security in the 21st Century: Perspectives on a Changing World; Valentin, N., Ed.; Cambridge Scholars Publishing: London, UK, 2014.

18. RG. Legea Energiei Electrice. Available online: http://www.cdep.ro/pls/legis/legis_pck.htp_act_text?idt= 49326 (accessed on 10 November 2016).

19. RG. Legea Energiei Electrice. Availabe online: http://www.dreptonline.ro/legislatie/legea_energiei_ electrice_13_2007.php (accessed on 11 November 2016).

20. RG. Legea Pentru Stabilirea Sistemului de Promovare a Producerii Energiei din Surse Regenerabile de Energie. Availabe online: http://www.dreptonline.ro/legislatie/legea_220_2008_sistemul_promovare_ producere_energie_surse_regenerabile_energie_republicata_2010.php (accessed on the 12 November 2016).

21. Paun, D.; Paun, C.A. The Impact of Renewable Energy on the Price of Energy in Romania. Int. J. Renew. Energy Res. 2017, 7, 540-546.

22. Gavriletea, M.; Gavriletea, M. The Investment Problematic For Producing Energy From Renewable Sources In Romania. Theor. Appl. Econ. 2009, 12 (Suppl. 12), 498-504.

23. Friedlob, G.T.; Schleifer, L.L. Essentials of Financial Analysis; Wiley: Hoboken, NJ, USA, 2002.

24. Wild, J.J.; Bernstein, L.A.; Subramanyam, K.R. Financial Statement Analysis, 7th ed.; McGraw-Hill Higher Education: New York, NY, USA, 2001.

25. Berk, J.B.; DeMarzo, P.M. Corporate Finance, 4th ed.; Pearson: Essex, UK, 2017.

26. Damodaran, A. Price and Value to Book Ratio by Sector (US). Available online: http:/ / pages.stern.nyu.edu/ adamodar/ (accessed on 15 May 2017).

27. Leal-Rodríguez, A.L.; Albort-Morant, G. Linking Market Orientation, Innovation And Performance: An Empirical Study on Small Industrial Enterprises In Spain. J. Small Bus. Strateg. 2016, 26, 37-50.

28. Zulu-Chisanga, S.; Boso, N.; Adeola, O.; Oghazi, P. Investigating the Path from Firm Innovativeness to Financial Performance: The Roles of New Product Success, Market Responsiveness, and Environment Turbulence. J. Small Bus. Strateg. 2016, 26, 51-67. 